\title{
Federal Constitutional Court To Decide Whether to Issue a Temporary Injunction Against Germany's New Lifetime Partnerships Law for Homosexual Couples
}

\author{
By Andreas Maurer \\ Suggested Citation: Andreas Maurer, Federal Constitutional Court To Decide Whether to Issue a Temporary \\ Injunction Against Germany's New Lifetime Partnerships Law for Homosexual Couples, 2 German Law Journal \\ (2001), available at http://www.germanlawjournal.com/index.php?pagelD=11\&artID=42
}

[1] On July 18, 2001, the Bundesverfassungsgericht (German Federal Constitutional Court) will issue its ruling in the application for a temporary injunction, (1) brought by the Länder (Federal States) of Bavaria and Saxony, to block the August 1 effective date of the new federal Lebenspartnerschaftgesetz (LPartG -- Registered Lifetime Partnership Act for Homosexual Relationships). (2) This act has been the subject of considerable controversy including the claims at the heart of the Federal States' challenge to the constitutionality of the statute. (3) This article will: (a) briefly survey the social evolution that has necessitated the regulations in this statute; (b) describe some of the statute's provisions; and (c) end by summarizing some of the sometimes harsh and often very emotional arguments involved in the debate over the LPartG and raised as part of the challenge to the statute's constitutionality in the proceedings before the Federal Constitutional Court.

\section{The LPartG In Brief}

[2] The LPartG constitutes a new framework for the public recognition of homosexual relationships, governed according to standards that, until now, have only been relevant to married, opposite-sex couples. The LPartG transfers these standards, albeit not in their entirety, to homosexual couples through the institution of a publicly recognized relationship known as the registered lifetime partnership. The new status created by the statute affects aspects of taxation, housing and rent, immigration, child adoption, joint ownership of property, the legal status of the surviving dependant and many other matters.

\section{The Social Evolution Leading to the LPartG}

[3] Even in Europe it has not been taken as self-evident that homosexual partnerships should be given the same standing under the law as married, opposite-sex couples. The issue remains the subject of heated debate. Many discussions in politics as well as in other sectors of society have lead the way to a new evaluation of the issue and the recent creation of the LPartG. The development can be summarized as follows: As recently as 1957 the Federal Constitutional Court ruled that criminalizing male homosexuality was not unconstitutional; (4) today the prosecution of homosexuality is considered inconsistent with human rights. (5) During the last thirty years a dramatic change of the social response to homosexuality has taken place. Public opinion polls in recent years have shown that a majority now approves of extending equal standing to homosexual partnerships and traditional, opposite-sex marriages. This social evolution is reflected in several provisions of European Union law (including the EU Charter of Fundamental Rights, which, at this point, has only moral authority over the Member States) as well as in the anti-discrimination provisions in the constitutions of many German Federal States. Even the German Army has adapted its regulations concerning homosexual soldiers, in so far as homosexuality is no longer a reason for exclusion from service. Those developments mark the way from the suppression of homosexuality to the LPartG, which establishes clear legal claims for equality for homosexuals.

\section{The LPartG In Detail}

[4] The LPartG mainly copies the part of the Bürgerliches Gesetzbuch (BGB -German Civil Code) that governs marriage between members of the opposite sex (husbands and wives).(6) Nevertheless many regulations were changed, partly in favor of the homosexual couple and partly to their disadvantage. The following description of some of the differences between the rights and privileges of a married couple and those that will be extended to partners by the LPartG is certainly not exhaustive, but it covers some of the most important aspects of the new law:

\section{a) Preconditions}

[5] The Lifetime-partnership, like an opposite-sex marriage, is established by the statement of the partners (while both are present) that they want to enter into a partnership. A husband and wife in an opposite-sex marriage are expected to share the same surname and pursuant to the LPartG the lifetime-partners can also share the same surname. Interestingly, a registrar "celebrates" the marriage of the opposite-sex couple while the lifetime-partnership must be "confirmed" by a public authority that will be specified by every federal state.

b) Duration 
[6] While statutory regulations regarding marriage require that it is (at least in principle) a life-long commitment, (7) the same-sex lifetime partnership serves only as a kind of "letter of the participants' intent" that they want to stay together for their lifetime. The parliament has made clear that marriage is inherently a life-long relation between two people (of the opposite sex) and that this shall be seen as a mandatory principle of the marital institution. The samesex lifetime partnership, on the other hand, only reflects the declaration of the intention to live together for a lifetime. This is a questionable and unnecessary valuation, especially in light of the increasing number of divorces.

\section{c) Property}

[7] Marriage automatically creates, if not otherwise established in an individual marital agreement, a Zugewinngemeinschaft (the wealth brought into the marriage remains the property of the individuals). If one partner acquires more wealth than the other during the marriage, he or she must transfer half of that wealth to the other in case of a divorce. By contrast, the lifetime partnership cannot be established unless the potential members of the partnership reach agreement in advance on the status of their property. That could take the form of a Zugewinngemeinschaft (as is assumed in opposite-sex marriages) but the couple could also agree to novel terms in a contract that has to be countersigned by a notary. It makes sense that two people who want to share their lives together make clear how their wealth should be shared. It seems questionable, however, that this affirmative choice is not required of married couple as well. In this detail it again appears that the parliament considered the lifetime partnership to be more an economic and legal status for the partners and less an emotional relationship. (8)

\section{d) Termination}

[8] In the event that same-sex partners choose to separate but have not yet terminated the partnership, they have the same rights that husband or wife have in the same circumstances: reasonable alimony, distribution of the contents of the residence and the right to have an appropriate, separate space in the shared apartment or house. There is, however, a difference between lifetime partners and a married couple with respect to reasonable alimony. While claims for alimony are rejected only in cases of an obvious injustice in a marriage, in the lifetime partnership a claim for alimony shall be refused at a much lower threshold, in cases of a simple inequity. The assumption with respect to the lifetime partnerships is that each partner provides for his or her own sustenance. The final termination of the lifetime partnership has fewer formal preconditions than are required for a divorce in a marriage. The termination of both relationships must be adjudicated by a court. But the lifetime partnership can be terminated after one year if both partners have stated their desire for a final termination and after three years if only one partner has done so. The precondition for the termination of a marriage, on the other hand, is the "disruption of the marriage," that is to say -the collapse of the relationship. The mandatory indication of such a disruption is the separated living conditions of the married couple for one year if the divorce is not contested and three years if only one party desires the divorce. However, even if the formal preconditions for the termination of a lifetime partnership are easier to fulfill, the termination is in fact more difficult because of the date from which the one-year or three-years time period begins to run starts with the official declaration of intent to terminate of one or both of the partners, regardless if they have been living separately for a longer period or not. For a married couple, the time period runs from the time the husband and wife actually begin living separately, even if that precedes an official declaration of intent to divorce.

\section{e) Legal Status of the Surviving Dependant}

[9] Regarding the law of succession, lifetime partners will generally have the same legal status as that of a married couple, including the opportunity to make a joint will and testament. A highly relevant question in practice is whether the surviving dependant can enter into a tenancy agreement or not. This right is provided to lifetime partners by the LPartG with one limitation: A husband and wife can enter into a tenancy agreement, but their children cannot. In contrast, a lifetime partner has to accept that the other partner's children can also enter into this agreement with their parent, if they so desire.

\section{f) Children / Adoption}

[10] Regarding adoption, the LPartG discriminates against the homosexual couple. They do not have the opportunity to jointly adopt a child. Only one of the partners can adopt a child and therefore has sole custody of the child. This regulation is in accordance with regulations for heterosexual partnerships that are not a married. It is also not possible, within the framework of the LPartG, for one homosexual partner to adopt the other partner's child. If such an adoption would occur the consequence would be that the adopting partner would assume the legal status of the parent and the biological parent (the other partner) would lose that status with respect to his or her own child. A relevant innovation for homosexuals in a lifetime partnership is the so-called "small custody" status. That status empowers the stepfather or stepmother in an opposite-sex marriage or the non-custodial parent in a lifetime partnership to make decisions for the child in matters of the daily life. 


\section{The Constitutional Challenge to the LPartG}

[11] The challenge to the constitutionality of the LPartG involves a number of constitutional provisions, including: (a) an alleged violation of the constitutional provisions concerning legislative procedure; (b) an alleged violation of Article 6 (1) of the Grundgesetz (GG -- Basic Law), which establishes the rights associated with families; and (c) an alleged violation of Article $3 \mathrm{GG}$, which is the constitution's equality provision.

\section{a) Legislative Procedure}

[12] The parliament's constitutional authority to create the LPartG has been challenged. Depending on their content, some statutes can be passed by the parliament alone while other statutes also require approval of the second parliamentary chamber (Bundesrat - the chamber charged with representing the interests of the Federal States). It is has become a common strategy, when (as is presently the case) the governing parliamentary coalition lacks a majority in the Bundesrat, to split a single law into two statutory proposals. One of them can then be tailored for passage in the parliament, permitting some of the regulations to take effect. The related statutory proposal can then be stripped-down to only those provisions that must also be approved by the Bundesrat (where the governing coalition lacks a majority) where it will likely be defeated. This strategy does not offend the constitution so long as there is an objective reason for the split. The LPartG was split in the described way during its parliamentary consideration in the fall of 2000. The obvious reason for the split of the LPartG, performed after it had become clear that the Bundesrat would not approve law as a whole without dramatic changes, was to circumvent the Bundesrat. (9) Under the aspect of legislative authority, there are legitimate questions regarding the LPartG.

\section{b) Violation of Article 6 (1) of the Basic Law}

[13] The challenge to the LPartG based on Article 6 (1) of the Basic Law claims that Article 6 creates special constitutional protections for the marital institution, narrowly defined as the association of a man and a woman in an inseparable relationship, (10) and that the parliament has unconstitutionally transferred the unique constitutional protections associated with marriage to a status (same-sex lifetime partnerships) that is not recognized by the constitution. This argument assumes that Article $6(1)$ of the Basic Law not only creates individual rights that a married couple can assert over and against the state, but also an institutional guarantee that binds the legislator in matters of marital and family legislation. The definition of marriage explicitly draws on the distinct genders of the participants (husband and wife) and the challenge to the LPartG argues that marriage is therefore available only for heterosexual couples. The challenge argues that, If the parliament transfers the regulations for heterosexual couples to homosexual couples (even if it uses the novel terms "lifetime partnership") it thereby nullifies Article 6's valuation of marriage and the accompanying protections Article 6 provides. (11) Supporters of the LPartG respond that the LPartG is not the basis for a "homo-marriage,"(12) but creates a completely new legal basis for homosexual relationships. (13) Supporters of the LPartG also argue that, while Article 6 (1) of the Basic Law indisputably provides an institutional guarantee for the protection of marriage and family, there is also clearly no "mandate" in the constitution to "combat other forms of social interaction." As the broader social valuation of homosexuality has changed, the position argued by the opponents of the LPartG reflects a historically-fixed interpretation of the constitution. Now it seems more appropriate to limit protection provided by Article 6(1) of the Basic Law to a prohibition of an impairment on the right to marry. (14)

\section{c) Violation of Article 3 of the Basic Law}

[14] Article 3 of the Basic Law guarantees equality, making special provision for the equality of men and women and prohibiting discrimination based on sex, heritage, race, religion, origin and political attitudes. The challengers of the LPartG claim that the registered lifetime partnership discriminates because it is not equally available to heterosexual couples and other kinds of associations (like polygamy, for example). Supporters of the law claim that the availability of marriage to heterosexual couples is sufficient to negate the possible discriminatory nature of the lifetime partnership, limited as it is to homosexual partners. (15)

\section{Future Perspectives}

[15] Whether or not the Federal Constitutional Court grants the temporary injunction blocking the entry into force of the LPartG on August 1, it is obvious that the changed social response to homosexual relationships requires that homosexual couples, at least in legal and economical aspects, be given standing equal to that of married, oppositesex couples. Defeat of the LPartG (in these provisional proceedings or later in the substantive proceedings) will clearly only be a temporary set-back. The social evolution that began several decades ago, that today finds its apex in the LPartG, does not appear headed for a reversal regardless of the perspective of the Federal Constitutional Court. 
[16] German Law Journal will report more fully on imminent decision of the Federal Constitutional Court in the temporary injunction proceedings.

(1) Article 32 of the Bundesverfassungsgerichtgesetz (BVerfGG -- Federal Constitutional Court Act) oultines the procedure for obtaining a temporary injunction from the Federal Constitutional Court: "In a dispute the Federal constitutional Court may deal with a matter provisionally by means of a temporary injunction if this is urgently needed to avert serious detriment, ward off iminenet force of for any other important reason of the common good."

(2) See the website of the Federal Ministry of Justice on this particular topic (text in English):

http://www.bmj.bund.de/misc/e sasepa.htm

(3) The substantive challenge to the statute is an abstract judicial review proceeding brought by the two Federal States that doubt the "substantive compatibility of federal law . . . with the Basic Law [constitution]." Article 93(1)(2) of the Grundgesetz (Basic Law). In principle, the Court's ruling on the requested temporary injunction should have no effect on and should not influence the Court's consideration of the underlying substantive application, which will proceed through the normal channels and at the normal pace of the Court's docket after the Court's ruling on the requested temporary injunction.

(4) BVerfGE 6, 389.

(5) Dudgeon v. The United Kingdom, No. 07525/76, http://hudoc.echr.coe.int (European Court of Human Rights, February 24, 1983).

(6) Kaiser, JURISTENZEITUNG 2001, p. 617.

(7) Section 1353 para. 1 sent. 1 BGB.

(8) Kaiser, JURISTENZEITUNG 2001, p. 620.

(9) Scholz/Uhle, NEUE JURISTISCHE WOCHENSCHRIFT 2001, p. 394, 395.

(10) Dreier GG, Band 1 1996, Art 6 Rn. 26.

(11) Scholz/Uhle, NEUE JURISTISCHE WOCHENSCHRIFT 2001, 394, 395.

(12) This phrase has been used by the press, e.g. DIE WELT 03/29/2001.

(13) Beck, NEUE JURISTISCHE WOCHENSCHRIFT 2001, p. 1894, 1898.

(14) Beck, NEUE JURISTISCHE WOCHENSCHRIFT 2001, p. 1894, 1899.

(15) Beck, NEUE JURISTISCHE WOCHENSCHRIFT 2001, p. 1894, 1900. 